\title{
Determination of the main bioaerosol components using chemical markers by liquid chromatography-tandem mass spectrometry
}

\author{
Francesca Buiarelli ${ }^{\mathrm{a}, *}$, Elisa Sonego ${ }^{\mathrm{a}}$, Daniela Uccelletti $^{\mathrm{b}}$, Erika Bruni ${ }^{\mathrm{b}}$, Patrizia Di Filippo ${ }^{\mathrm{c}}$, \\ Donatella Pomata ${ }^{\mathrm{c}}$, Carmela Riccardi ${ }^{\mathrm{c}}$, Cinzia Perrino ${ }^{\mathrm{d}}$, Francesca Marcovecchio ${ }^{\mathrm{d}}$, \\ Giulia Simonetti ${ }^{\mathrm{a}}$ \\ ${ }^{a}$ Department of Chemistry, Sapienza University of Rome, Piazzale Aldo Moro, 5-00185, Rome, Italy \\ b Department of Biology and Biotechnology “Charles Darwin", Sapienza University of Rome, Piazzale Aldo Moro, 5 - 00185, Rome, Italy \\ ${ }^{\mathrm{c}}$ DIT, INAIL, Via Roberto Ferruzzi 38, 00143 Rome, Italy \\ ${ }^{\mathrm{d}}$ C.N.R. Institute of Atmospheric Pollution, Via Salaria km 29.300, C.P. 10, 00016, Monterotondo Stazione, Rome, Italy
}

\section{A R T I C L E I N F O}

\section{Keywords:}

Bioaerosol

Chemical biomarkers

Airborne bacteria

Fungi

Algae

Airborne particulate matter

PM

\begin{abstract}
A B S T R A C T
This work is part of an extensive research project aimed at the determination and characterization of bioaerosol with a multidisciplinary approach.

In this context, one of the main objectives of the project has been the development of a comprehensive analytical method for the determination of different chemical biomarkers of the bioaerosol, by liquid chromatography coupled with tandem mass spectrometry.

The following biomarkers have been considered, and correlated to specific components of bioaerosol as unambiguous indicators:

- ergosterol $\rightarrow$ fungal components

- chlorophylls, phytosterols (stigmasterol and b-sitosterol), $\alpha$-tocoferol $\rightarrow$ vegetable cells and algae

- cholesterol $\rightarrow$ animal cells, vegetable cells and algae.

- dipicolinic acid $\rightarrow$ bacterial spores

- muramic and meso-2,6-diaminopimelic acid $\rightarrow$ bacterial cells

To verify the method, to find diagnostic ratios and to calculate the appropriate conversion factors, fungal spores, bacterial cells and spores, and algae of known species, commonly airborne, were analysed.

The material was subjected to freezing and de-freezing cycles, followed by extraction, hydrolysis and purification of the biomarkers. The chromatographic separation of the bacterial biomarkers was achieved by using a polymeric column, based on Hydrophilic Liquid Interaction with the electrospray ionization mass spectrometric detection, whereas sterols and chlorophylls were separated by a reversed phase column, coupled to atmospheric pressure chemical ionization - tandem mass spectrometer. The optimized method was applied to environmental particulate matter sampled in an outdoor site. Bacterial and fungal content was compared to the results obtained from the classical direct viable counting method in the sampled particulate matter.
\end{abstract}

\section{Introduction}

Bioaerosols are ubiquitous biological polluting agents and include pollen, intact and fragmented airborne microorganisms (viruses, bacteria, fungi, algae, spores etc.,) their metabolites, debris and excreta. They play an important role in the atmospheric processes and in the formation of secondary organic aerosols and have high sanitary impact, because of their negative respiratory health effects in a large percentage of the exposed population. The physio-pathological effects of bioaerosol depend on the nature, concentration, chemical-physical properties and size ranging from 0.001 to $100 \mu \mathrm{m}$ [1].

There are several methods for the quali/quantitative assessment of the bioaerosol components, after sampling of atmospheric particulate matter (PM). The alternative approach to microbial counts [2] and molecular biology methods [3-5] is based on the analysis of chemical biomarkers, i.e. on the determination of non-toxic chemical molecules being part of more complex bioactive structures. For the estimation of biomass, the biomarker must be present in an almost constant

\footnotetext{
* Corresponding author.

E-mail address: francesca.buiarelli@uniroma1.it (F. Buiarelli).
} 
concentration in the biological component of interest. Several authors have dealt with this topic, generally considering one biomarker at a time [6-9].

Since 2013, we have been interested in this matter [10,11]. For fungi, ergosterol is a well-tested and reliable biomarker at our latitude, whose conversion factor was previously measured, considering the most abundant fungal species found in the atmosphere [12,13]. Bacterial Spores and bacterial cells are different in how they function and how they are produced. The spores are dormant survival cells and spores are more durable and survive in less ideal conditions. Structurally a spore is more complex than the vegetative cell, because it contains more layers than vegetative cells. Dipicolinic acid (pyridine 2,6dicarboxylic acid, DPA), contained in the spore core as responsible for the heat resistance, has been proposed as bacterial spore biomarker, whereas, as bacterial cell biomarker, muramic acid (MUR), linked to peptidoglycan (PG) giving rigidity to the cell wall, has been established [14]. As for algae, it is well known that phytoplanktonic organisms are photoautotrophic vegetal organisms comprising unicellular (microalgae), multicellular (macroalgae) and colonial (micro and macroalgae) species $(1-10 \mu \mathrm{m})$. In suitable environmental conditions, algae can produce thick layers in surface water bodies and subsequently be airborne [15]. Algae have plastids containing chlorophyll and other photosynthetic pigments, which are of fundamental importance for the taxonomic study. Cyanobacteria, improperly called blue algae or bluegreen algae, often present in dust, air and surfaces [15], are Gram-negative photosynthetic bacteria, also containing chlorophyll A. The chlorophyll, a compound able to chelate metals, is found in the chloroplasts of plants and in all organisms performing photosynthesis, algae included. Chlorophyll consists mainly of a mixture of two compounds, chlorophyll A and chlorophyll B, commonly found in a 3:1 ratio. In the chloroplasts, chlorophyll is bound to lipoproteins and nucleic acids in complexes (chloroplastins), containing carotenes and xanthophylls. Therefore, chlorophyll represents a good marker for the presence of vegetable cells.

Among the phytosterols, plant sterols structurally similar to cholesterol, stigmasterol has been considered, since it is present in algae and in the Brassicaceae plants, mainly spread in the Mediterranean basin [16]. It is also present in various legumes and can be considered as a soy biomarker. Several studies, regarding the occurrence of stigmasterol in PM, have been conducted in places where soybeans are stored and processed $[17,18]$. Also $\beta$-sitosterol, that is the most abundant phytosterol in the diet, is widely distributed in the plant kingdom. From the chemical point of view, $\beta$-sitosterol has a structure very similar to that of cholesterol and differs from the latter for the presence of an ethyl group at the carbon- 24 position of the side chain. It can be considered a marker of plant cells. Cholesterol plays a particular important role in the physiology of animals, since it is a fundamental constituent of animal cell membranes and a precursor of vitamin D and bile acids. Cholesterol, the only kind of lipid in the body having a rigid ring structure, is found in the plasma membrane and, due to the presence of the side chain, its functions cannot be replaced by phytosterols. Cholesterol is also a constituent of the myelin sheath of the nerves. For these characteristics, cholesterol can be considered a good biomarker of animal cells. Despite to common opinion, it is also present in plant and algae cells, but at lower concentration $[19,20]$ and it is virtually absent in prokaryotic cells. As regard all the sterols, there are very few papers that deal with their quantization in bioaerosol [21]. Several authors found them in biomass burning [22].

To the aim of characterizing the different bioaerosol components, through chemical markers, we chose:

- ergosterol for fungal components,

- stigmasterol, $\beta$-sitosterol (phytosterols), $\alpha$-tocoferol and chlorophyll for vegetable cells and algae,

- cholesterol for animal cells, algae and vegetable cells,

- dipicolinic acid for bacterial spores,
- muramic for bacterial cells.

In this last case, we also proposed the meso-2,6-diaminopimelic acid (MDPA) with the double aim to have a further marker of gram-positive and gram-negative bacterial cells and to recalculate and/or re-check the bacterial conversion factors. Although the peptidoglycan (PG) composition is species specific, MDPA is the third dibasic amino of the tetrapeptide of enzymatic synthesis linked to $N$-acetylmuramic of the cell wall of most Gram-positive and Gram-negative bacteria.

Therefore, it is really a challenge to simultaneously analyse all the above-mentioned compounds from the same matrix, since no one of the biomarkers, considered singularly, can be fully reliable for the determination of the specific complex biological structures.

We focused the study on bacteria, fungi and algae species, among the most widespread in air, in order to 1) verify the method, 2) find out particular and diagnostic relationships/ratios between the biomarkers, if present 3) find/recalculate the appropriate conversion factors. After a preliminary extraction, hydrolysis and purification of the biomarkers from fungi, bacteria and algae, we determined, or confirmed, when possible, the appropriate factors to convert marker values into biomass and we tested the method reliability and its applicability on airborne particulate matter of aerodynamic diameter $\left(D_{a}\right)$ between 1 and $10 \mu \mathrm{m}$ $\left(\mathrm{PM}_{>1}\right)$ or less of $1 \mu \mathrm{m}(\mathrm{PM}<1)$, on purpose sampled.

The proposed method was applied to environmental particulate matter sampled in an outdoor site, collecting the fractions of PM and the results were compared to those obtained with the classical microbiological approach of counting viable microorganisms after cultivation, considering the two methods differ for non-viable and non-cultivable species.

The proposed methodology provides a useful tool for further academic studies. However, it is necessary to highlight that, to characterize the entire bioaerosol population and to obtain a correct interpretation of the data, a careful comparison among the available detection methods is required, since the different disciplines involved in the survey can provide complementary information [23].

\section{Materials and methods}

\subsection{Chemicals and material}

A list of the standards, reagents with the relative brands was reported in Table S1 of supporting information. Stock standard solutions of them were prepared in $\mathrm{H}_{2} \mathrm{O} /$ Propan-2-ol (IPA) $=50 / 50 \mathrm{v} / \mathrm{v}$ $1 \mathrm{mg} \mathrm{mL}^{-1}$ and stored at $-20{ }^{\circ} \mathrm{C}$ in the dark. The working standard solutions were daily prepared by diluting properly stock solutions with mixture of $\mathrm{H}_{2} \mathrm{O} / \mathrm{MeOH}(50 / 50, \mathrm{v} / \mathrm{v})$.

Strata $\mathrm{C}_{18}-\mathrm{E} \quad(500 \mathrm{mg} / 6 \mathrm{~mL})$ cartridges were obtained from Phenomenex srl (Bologna, Italy).

To quickly elute the analytes from SPE cartridges at constant flow, a vacuum manifold 12-Port model SPE (Alltech, Casalecchio di Reno, Bologna, Italy) was used. Solvent evaporation was performed by Evaporator SE 500s-Dionex (Dionex, Sunnyvale, CA, USA).

\subsection{Microbial and algae cultivations}

Microbial cells and spores used in this work were reported in Table S2 of supporting information.

Bacterial cells were grown in liquid microbial growth medium-LB broth (Lennox)-(Sigma-Aldrich Milan, Italy) made of the following components $10 \mathrm{~g} / \mathrm{L}$ tryptone, $5.0 \mathrm{~g} / \mathrm{L}$ of yeast extract, and $5 \mathrm{~g} / \mathrm{L}$ of $\mathrm{NaCl}$, at $37^{\circ} \mathrm{C}$ over-night, while spores were prepared as described by $\mathrm{Di}$ Filippo [14]. Briefly, each strain was inoculated in $35 \mathrm{~mL}$ of Difco Sporulation Medium (DSM), and incubated at $37^{\circ} \mathrm{C}$ on a rotary shaker (150 rpm) for $72 \mathrm{~h}$. Difco Sporulation Medium, is a complex medium made of bacto nutrient broth $8 \mathrm{~g} / \mathrm{L}, \mathrm{KCl} 1 \mathrm{~g} / \mathrm{L}$, and $\mathrm{MgSO}_{4} 0.25 \mathrm{~g} / \mathrm{L}$. After autoclaving, $1 \mathrm{~mL}$ of each of the following filter-sterilized 
solutions: $1 \mathrm{M} \mathrm{Ca}\left(\mathrm{NO}_{3}\right)_{2}, 0.01 \mathrm{M} \mathrm{MnCl}_{2}, 1 \mathrm{mM}$ FeSO 4 were added. Spores and cells were collected by centrifugation and washed twice with ice-cold distilled water. Fungi were grown on YPD plates (Yeast Extract-Peptone-Dextrose, Sigma-Aldrich Milan, Italy) at $20^{\circ} \mathrm{C}$. The spores were collected by several washing with sterile $\mathrm{H}_{2} \mathrm{O}_{\text {dd }}$ Finally, pellets of bacteria and fungi were dried in an oven at $65^{\circ} \mathrm{C}$ until constant weight was obtained.

Algal culture of Scenedesmus obliquus and Chlorella vulgaris was cultured in a flat plate-photobioreactor, under constant illumination and fed with $0.5 \mathrm{~L} / \mathrm{min}$ of $\mathrm{CO}_{2} /$ air $(0.05 / 1 \mathrm{v} / \mathrm{v})$. The growth medium was BG11 medium described by Rippka et al. [24].

\subsection{Sampling}

Two Micro-Orifice Uniform Deposition Impactors MOUDI (mod. $110 \mathrm{R}, \mathrm{MSP}$ ) were used to collect particulate matter at $30 \mathrm{~L} / \mathrm{min}$ sampling flow rate. Size-fractionated particle samples, in ten size intervals $(\leq 0.18,0.32,0.56,1.0,1.8,3.2,5.6,10$ and $18 \mu \mathrm{m}$ ), were collected over a $47 \mathrm{~mm}$ diameter sampling PTFE substrate [25]. The samplers were placed at the Research Area RM1 of the National Research Council of Italy in Montelibretti (Central Italy), a biogenically dominated background site at about $25 \mathrm{~km}$ from the city of Rome.

The sampling duration was 19 consecutive days (27 June to 16 July 2017), with a final volume of sampled air equal to $814 \mathrm{~m}^{3}$ at an average temperature of $23^{\circ} \mathrm{C}$.

The samplers were located inside a conditioned cabin, where $\mathrm{T}$ and RH were maintained constant. Nevertheless, in this study, the trauma of rapid flow rates $(30 \mathrm{~L} / \mathrm{min})$, dehydration and collision on filters, affecting the viability of some species of microorganisms was first checked by performing an auto consistency test.

Three samplers A, B, and C were positioned in parallel for fourteen days. Sampler A collected particles during the first week, sampler B collected particles for the second week and sampler $\mathrm{C}$ operated for the whole period. After, sampler A viable bioaerosol results were summed to sampler B results and compared with the outcomes of sampler $\mathrm{C}$ and proved to be consistent (data not shown). We concluded that the stress due to the collection mechanism was reduced, thanks to the temperature and humidity-controlled conditions, and for the collection system based on impaction instead of filtration. Moreover, a possible conversion of vegetative cells to spores could have preserved the viability of some bacteria.

To obtain the gravimetric size distribution of the particles, the filters (before and after sampling) were weighed using an analytical electronic balance (Sartorius MC-5, $\Delta \mathrm{m} \pm 0.001 \mathrm{mg}$ ) after conditioning in a climatic chamber (Activa Climatic Cabinet, Aquaria MI, according to UNI EN 12341/2001; UNI CHIM 285/2003 and D.M. 60/2002) for $24 \mathrm{~h}$, at $T=20 \pm 1{ }^{\circ} \mathrm{C}$ and at $50 \% \pm 5 \%$ relative humidity. For biomarker analysis, filters were gathered into two sets, corresponding to particle fraction with $\mathrm{Da}<0.18-1 \mu \mathrm{m}\left(\mathrm{PM}_{<1}\right)$, and particle fraction with $1 \mu \mathrm{m}<\mathrm{Da}<18 \mu \mathrm{m}\left(\mathrm{PM}_{>1}\right)$. The mass atmospheric concentrations of PM were about 9 and $20 \mu \mathrm{g} \mathrm{m}^{-3}$, respectively.

\subsection{Instrumentation and operating conditions}

Hydrophilic Liquid Interaction (HILIC) with the electrospray ionization (ESI) mass spectrometric detection was used for DPA, MUR and MDPA, whereas a reversed phase coupled to atmospheric pressure chemical ionization (APCI) tandem mass spectrometry was used for sterols and chlorophylls.

Chromatographic-mass spectrometric analyses were performed in multiple reaction monitoring (MRM) on a triple quadrupole mass spectrometer fitted with an autosampler. Instruments are reported in Table S3 of Supporting Material. The mobile phase (MP) for the analysis of MUR, DIP and MDPA consisted in $\mathrm{H}_{2} \mathrm{O}$ (MPA) and $\mathrm{CH}_{3} \mathrm{CN}$ (MPB). A step elution, changing sharply the mobile phase composition from $\left(\mathrm{H}_{2} \mathrm{O}-\mathrm{CH}_{3} \mathrm{CN}=5: 95\right)$, to $0.10 \mathrm{~min}\left(\mathrm{H}_{2} \mathrm{O}-\mathrm{CH}_{3} \mathrm{CN}=40: 60\right)$ and then after $2.1 \mathrm{~min}$ to $\left(\mathrm{H}_{2} \mathrm{O}-\mathrm{CH}_{3} \mathrm{CN}=65: 35\right)$, was used to perform the analysis at a working flow rate of $200 \mu \mathrm{L} \mathrm{min}^{-1}$. Source gas 1 , turbo gas 2 and curtain gas were set respectively to 30,40 and 30 (arbitrary units). For the other biomarkers the mobile phase consisted in $\mathrm{H}_{2} \mathrm{O}$ (MPA) and $\mathrm{CH}_{3} \mathrm{CN}-10 \%$ IPA (MPB). Starting from MPA 90\%-MPB 10\%, a gradient elution started up to MPB $100 \%$ in $1 \mathrm{~min}$, then hold $3 \mathrm{~min}$ in isocratic elution working at a flow rate of $300 \mu \mathrm{Lmin}^{-1}$. Nitrogen was the nebulizing and collisional gas. In order to perform MS and MS/MS analyses in full scan (mass range $m / z 50-500$ ) and in product ion mode, the optimal conditions of the mass spectrometers were obtained by tuning the electrical parameters and optimizing the collision energy (CE) for each compound, by infusion of standard solutions $\left(10 \mu \mathrm{g} \mathrm{mL}^{-1}\right)$ at $10 \mu \mathrm{L} \mathrm{min}^{-1}$. Condition and electrical parameters are reported in Table S3 and S4 of Supporting Material.

\subsection{Sample preparation}

In summary the procedure included freezing and thawing cycles of the material, extraction with an organic solvent, ultrasound in the presence of glass marbles, vortexing, hot chemical hydrolysis, purification of the hydrolysate with a solid phase extraction (SPE) cartridge, sample filtration and finally liquid chromatography tandem mass spectrometry (HPLC-MS-MS) analysis.

The definitive procedure adopted for the sample preparation is shown in Fig. 1.

In details fungal spore (about $10-40 \mu \mathrm{g}$ ), bacterial spores and cells, algae (1 mg each), blank filters added with standard, and sampled PM filters, were subjected to 7 freezing and thawing cycles $\left(-20^{\circ} \mathrm{C}\right)$ after addition of $0.2-1 \mathrm{~mL}$ of water in order to break the cell walls. The mechanical breaking process was completed by adding glass beads, stirring in ultrasound and using the vortex. The addition of 2,2,4-trimethylpentane (ISO) in this step was necessary for the extraction of the most hydrophobic biomarkers (sterols and $\alpha$-tocoferol) and of chlorophylls, after ultra-sounding and centrifuging. This step was repeated three times. In this phase, we tested the use of Accelerated Solvent Extraction (ASE), as alternative, but without yield improvement. Once the organic phase was separated from the aqueous phase, the organic solvent was dried, redissolved with a suitable mobile phase and then injected $(5 \mu \mathrm{L})$ into HPLC-APCI-MS-MS. At the same time, part of the aqueous solution was filtered and stored before the reunion to the final solution for the analysis in HPLC-ESI-MS-MS. For the extraction of MUR and MDPA acids the remaining aqueous solution was hydrolyzed in $6 \mathrm{~N}$ $\mathrm{HCl}$ for $3 \mathrm{~h}$ at a temperature of $105^{\circ} \mathrm{C}$. The choice of hydrolysis conditions was optimized in terms of times, $\mathrm{HCl}$ concentration and temperatures to improve the yield. Subsequently, after neutralization with $\mathrm{NH}_{3}$, the water solution was first purified through a liquid-liquid extraction with isooctane and then on a $\mathrm{C}_{18}$ cartridge, previously activated with $\mathrm{CH}_{3} \mathrm{CN}$. This last procedure involves the retention of the interferents and the elution of the analytes directly in the solvent loaded on the cartridge. The eluate was dried, dissolved in a small volume $(50 \mu \mathrm{L})$ of $\mathrm{MeOH}-\mathrm{H}_{2} \mathrm{O}=90: 10$ and filtered before the re-union with aqueous solution and HPLC-ESI-MS-MS analysis.

2.6. Method validation: calibration curves, linearity, matrix effect, limit of detection/quantification, recovery, precision

First, solvent calibration curves were built for each analyte using the external standard method. In the concentration ranges examined (Table 1), there was a linear relationship between signal and analyte concentration, for all the analytes under consideration, as shown by determination coefficient $\left(\mathrm{R}^{2}\right)>0.99$. Matrix effect, calculated according to Buiarelli [26], resulted not negligible for bacterial biomarkers (MUR, DPA, MDPA). Therefore, due to the complexity of the matrices, affecting the instrumental response, the quantitative results were obtained by the standard addition method. In this case, environmental PM samples were extracted following the optimized method, the 


\section{Analytical procedure}

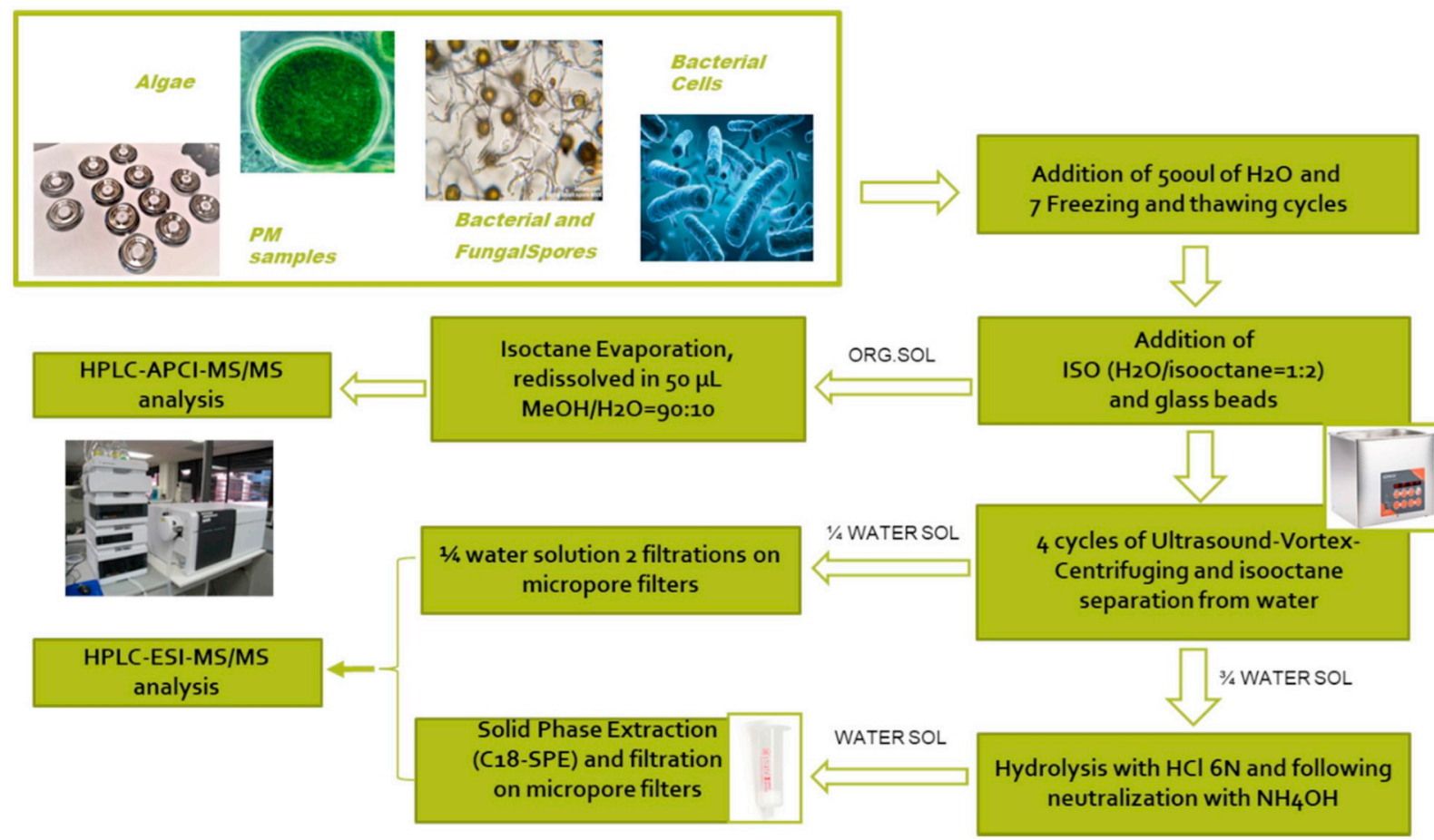

Fig. 1. Diagram of the analytical procedure for the extraction and purification of the analytes from spores, cells and sampled filters.

solutions were separated in six aliquots, five of them were added with multi-standard solutions with increasing concentration corresponding to those of the solvent curve. The concentration of the analytes in environmental samples was calculated by extrapolation of the least squares line intersecting the negative $\mathrm{x}$-axis [27].

Instrumental limit of detection (LOD) and limit of quantification (LOQ) were determined as the standard concentration producing a signal at least three and ten times the noise response. Matrix LOD/LOQ were determined by spiking a blank filter with the compounds before the whole procedure. The concentration producing a peak with a signalto-noise ratio $(\mathrm{S} / \mathrm{N})$ of 3 was chosen as LOD, whereas LOQ was estimated, using the criterion of $(\mathrm{S} / \mathrm{N})$ of 10 with a precision at least of $20 \%$ and an accuracy within $80-120 \%$.

Intraday reproducibility, expressed as RSD, was evaluated analysing three times, in the same day, in three different periods (morning, afternoon, evening), a sample solution at three different concentrations of the analytes. Interday reproducibility was obtained analysing the same solutions in three consecutive days.

Recovery was evaluated adding a standard solution of known concentration to a sample and applying the following Formula (1) [28].

$X=\frac{(b-a)}{c} x 100$

where

Table 1

Validation parameters for the investigated analytes by HPLC-MS-MS.

\begin{tabular}{|c|c|c|c|c|c|c|c|}
\hline Class & $\begin{array}{l}\text { Intraday repeatability } \\
(\mathrm{RSD} \%) n=10\end{array}$ & $\begin{array}{l}\text { Interday repeatability } \\
(\mathrm{RSD} \%) n=5\end{array}$ & Recovery (\%) & Linearity $\left(R^{2}\right)$ & $\begin{array}{l}\text { LOD } \\
\left(\mathrm{ng} \mathrm{mL}^{-1}\right)\end{array}$ & $\begin{array}{l}\text { LOQ } \\
\left(\mathrm{mg} \mathrm{L}^{-1}\right)\end{array}$ & $\begin{array}{l}\text { Concentration range } \\
\left(\mathrm{ng} \mathrm{mL} \mathrm{m}^{-1}\right)\end{array}$ \\
\hline Chlorophylls & 1 & 7 & $<10$ & 0.99998 & 100 & 300 & LOQ 3500 \\
\hline Sterols and $\alpha$-tocoferol & 2 & 8 & 90 & 0.9999 & 200 & 500 & LOQ-3500 \\
\hline Dipicolinic, Muramic, & 0.5 & 2 & 78 & 0.9987 & $3-10$ & $10-30$ & LOQ-1000 \\
\hline Mesodiamminopimelic acids & & & & 0.9970 & $6-20^{\mathrm{a}}$ & $20-60^{\mathrm{a}}$ & \\
\hline
\end{tabular}

\footnotetext{
a Value in matrix.
}

- "a" is the concentration of analyte found in the sample before addition of standard solution, if present.

- " $\mathrm{b}$ " is the concentration of analyte found after addition of standard solution.

- "c" is the concentration added.

Values $>80 \%$ and $<120 \%$ can be considered acceptable for analytical methods.

\section{Results and discussion}

\subsection{Optimization of sample preparation and data quality}

The optimization of the analytical procedure to be applied to the real samples (cells, spores and sampled filters) was globally the most laborious and complex part to be developed.

The sample preparation, shown in Fig. 1, has included the yield calculation of each phase and it represents the best compromise of multiple and repeated tests with different materials (cartridges, columns, solvents, volumes) and in different experimental conditions (number of cycles, hydrolysis conditions, time, temperature, pressure, etc.). Overall, on average, a recovery of over $80 \%$ was obtained for all the analytes, except for chlorophylls. Table 1 shows in detail the validation parameters for all the compounds. 
The linearity was checked by calibration curve both in solution and in matrix and showed to be good $\left(\mathrm{R}^{2}\right.$ at least $\left.>0.997\right)$. The intra-day reproducibility, calculated as average of the RSD obtained in the same day, was in the range $0.5 \%-3.0 \%$, whereas inter-day reproducibility ranged between $2 \%-10 \%$. Values averagely $\leq 10 \%$ can be considered acceptable for complex analytical methods and show a good reproducibility of method. LOD and LOQ matrix values are consistent with previous studies and demonstrate that the developed method allows to analyse the target compounds at trace levels in PM.

The lower recovery of chlorophylls is due to the choice of the extraction solvent not optimal for them.

\subsection{Optimization of mass spectrometry and liquid chromatography}

Table S4 (supporting information) summarizes, for each analyte, the compound name, the molecular weight (MW), the ionization source, the source polarity, the precursor ion, the quantifier, the collision energy, the current discarge for APCI source, the IS voltage for ESI source and the retention time (Rt) used for the MRM acquisitions. The choice of appropriate chromatographic conditions proved to be particularly laborious, due to the different nature of the molecules under investigation. For this purpose, several stationary phases were tested and different solvent mixtures, with different elution gradients, were used as mobile phases. To improve the shape of the peaks, it was mandatory the addition of a small percentage of propan-2-ol (10\%) to the mobile phase.

For the muramic, dipicolinic and mesopimelic acids, the inverse phase was not selective, due to the extreme polarity of the compounds. In this case, the use of hydrophilic liquid interaction chromatography (HILIC) allowed obtaining an adequate retention of the compounds as shown in Fig. 2.

\subsection{Analysis of real samples}

To verify the method, to confirm/recalculate the conversion factor we applied it first to fungal, bacterial and algae species commonly airborne and successively to an environmental outdoor sample.

For the quantitative analysis of the chemical markers in bacteria, fungi and algae the standard calibration curves were used, since the matrix effect was negligible. For particulate matter samples, due to strong matrix interferences, the standard addition method was mandatory only for the determination of MUR, MDPA and DPA.

\subsubsection{Bacteria}

The determination of MUR and MDPA, after hydrolysis has been verified on several representative airborne species: Bacillus mycoides, Bacillus subtilis, Bacillus simplex, Bacillus megaterium, Bacillus cereus (Gram-positive), Escherichia coli and Pseudomonas aeruginosa (Gramnegative), in order to find reliable conversion factors. The dried biomass of each bacterial species was extracted and analysed according to Fig. 1. Table 2 shows the values in $\%$ and $\mathrm{ng} / \mathrm{mg}$ of the two compounds in relation to the investigated bacteria, as mean of three replicate aliquots, with values of coefficient of variation, $\mathrm{CV},<10 \%$.

The percentage of muramic acid in cells ranged between 0.2 and $0.9 \%$. Mesodiaminopimelic acid, on average, was between three and six time lower than muramic acid, confirming its presence in both Grampositive and Gram-negative, except Bacillus simplex where it is absent. Assuming a percent of atmospheric abundance of $80 \%$ and $20 \%$ for gram positive and gram negative respectively [30,31], we calculated the conversion factors as a weighted average (WA) of marker concentrations obtained by processing each bacterium. Table 3 shows the conversion factor, calculated using the following Formula (2), to correlate the two biomarkers to the bacterial content;

$W A=\frac{\sum B i P i}{\sum P i}$

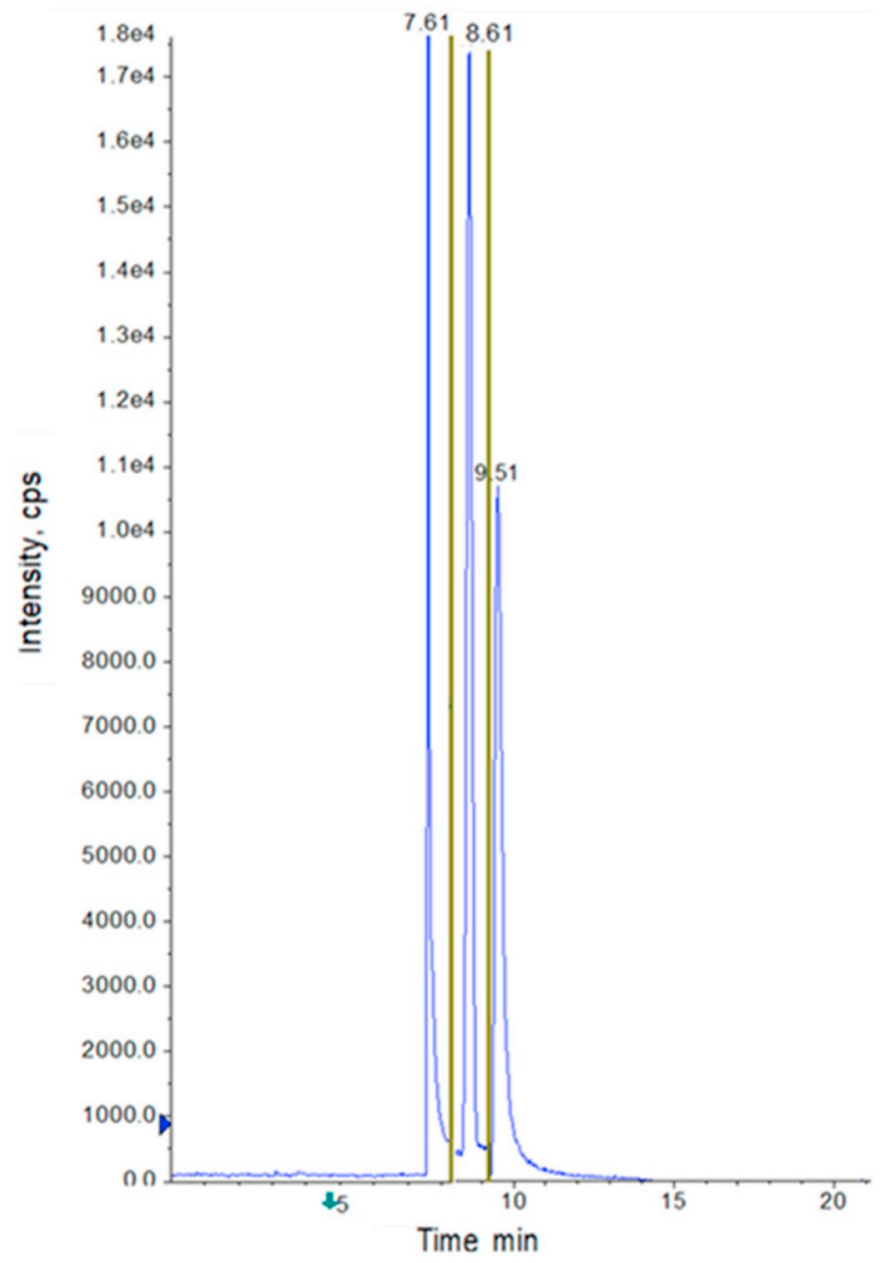

Fig. 2. XIC (extract ion) chromatogram in MRM mode of a standard solution of DPA (Rt 7.6 min), MUR (Rt 8.6) and MDPA (Rt $9.5 \mathrm{~min}$ ) acquired by HPLC-ESIMS-MS system. The vertical lines refer to three different acquisition windows. Column and mass spectrometric conditions as in table S3 and S4. MPA (Water) $5 \%$ and $\mathrm{MPB} \mathrm{CH}_{3} \mathrm{CN} 95 \%$ in step elution as in section instrumentation 2.3. Flow rate $300 \mu 1 \mathrm{~min}^{-1}$.

where $B i$ is the biomarker concentration expressed as averaged percentage (from Table 2), $P i$ is the percentage in atmosphere of gram positive and negative (see above). $\Sigma P i=1$.

Both the biomarkers were used for the determination of bacterial contribution in PM.

As for spores, Table 4 shows the dipicolinic acid values both as $\%$ and as $\mathrm{ng} / \mathrm{mg}$ in relation to the relative bacterium, as mean of three replicate aliquots, with $\mathrm{CV}$ values $<10 \%$.

The percentage of dipicolinic acid in spores ranged from 5 to $15 \%$ with an average of about $10 \%$, confirming previous results [14].

\subsubsection{Fungal spores}

Although the conversion factor of ergosterol is well established, fungal spores were processed with the aim of confirming it and at the same time of determining the eventual presence of other sterols. $500 \mu \mathrm{l}$ of solution containing $2 \times 10^{5}$ spores of the Stachybotrys cartharum fungus (corresponding to13 $\mu \mathrm{g}$ ), $500 \mu \mathrm{l}$ of solution containing $5.7 \times 10^{5}$ spores of a mold called Fusarium moniliforme (corresponding to $37 \mu \mathrm{g}$ ) and $500 \mu \mathrm{l}$ of solution containing $0.5 \times 10^{5}$ spores of a mold called Aspergillus niger (corresponding to $7 \mu \mathrm{g}$ ) were processed according to the scheme of Fig. 1; tests were carried out in triplicate, with $\mathrm{CV}$ values $<10 \%$. The concentration $(\mathrm{w} / \mathrm{w})$ of ergosterol found in Stachybotrys cartharum, in Fusarium moniliforme and in Aspergillus niger was $1.2 \mathrm{ng} / \mu \mathrm{g}, 3.7 \mathrm{ng} / \mu \mathrm{g}$ and $2.3 \mathrm{ng} / \mu \mathrm{g}$, respectively. These values are in 
Table 2

Concentration and percentage of MUR and MDPA in different bacterial cells.

\begin{tabular}{|c|c|c|c|c|c|c|c|}
\hline \multirow[t]{2}{*}{ Taxonomy } & \multirow[t]{2}{*}{ Cells } & \multicolumn{3}{|c|}{ Muramic acid } & \multicolumn{3}{|c|}{ Meso-2,6-diaminopimelic acid } \\
\hline & & $\mathrm{ng} / \mathrm{mg}$ & $\%$ & $\%$ average & $\mathrm{ng} / \mathrm{mg}$ & $\%$ & $\%$ average \\
\hline \multirow[t]{5}{*}{ Gram-positive } & Bacillus mycoides & $2.2 \times 10^{3}$ & 0.23 & 0.69 & $1.6 \times 10^{3}$ & 0.16 & 0.12 \\
\hline & Bacillus subtilis & $6.1 \times 10^{3}$ & 0.61 & & $1.3 \times 10^{3}$ & 0.13 & \\
\hline & Bacillus simplex & $1.1 \times 10^{4}$ & 1.1 & & - & - & \\
\hline & Bacillus megaterium & $9.0 \times 10^{3}$ & 0.90 & & $0.2 \times 10^{3}$ & $0 . \overline{0} 21$ & \\
\hline & Bacillus cereus & $6.4 \times 10^{3}$ & 0.64 & & $1.8 \times 10^{3}$ & 0.18 & \\
\hline \multirow[t]{2}{*}{ Gram-negative } & Escherichia coli & $3.8 \times 10^{3}$ & 0.38 & 0.28 & $1.4 \times 10^{3}$ & 0.14 & 0.088 \\
\hline & Pseudomonas aeruginosa & $1.9 \times 10^{3}$ & 0.19 & & $0.4 \times 10^{3}$ & 0.037 & \\
\hline
\end{tabular}

Table 3

Conversion factor obtained and used to correlate the two biomarkers to the bacterial content, calculated as weighted with Formula (2).

\begin{tabular}{lccc}
\hline & Gram-positive & Gram-negative & Average factor \\
\hline \% Atmospheric bacteria & 80 & 20 & \\
\% Muramic acid & 0.69 & 0.28 & 0.61 \\
\% Diamminopimelic acid & 0.12 & 0.088 & 0.11 \\
\hline
\end{tabular}

Table 4

Concentration and percentage of DPA in different bacterial spores.

\begin{tabular}{llll}
\hline \multirow{2}{*}{ Taxonomy } & Spores & \multicolumn{2}{l}{ Dipicolinic acid } \\
\cline { 3 - 3 } & & $\mathrm{ng} / \mathrm{mg}$ & $\%$ \\
\hline \multirow{2}{*}{ Gram - positive } & Bacillus mycoides & $4.7 \times 10^{4}$ & 4.7 \\
& Bacillus subtilis & $1.4 \times 10^{5}$ & 15 \\
& Bacillus megaterium & $9.3 \times 10^{4}$ & 9.3 \\
& Average & & 9.7 \\
\hline
\end{tabular}

line with previous estimations obtained by other authors. All the other sterols were absent in the investigated molds, supporting ergosterol as the only reliable biomarker with a conversion factor of $3.2 \mathrm{ng}$ ergos-

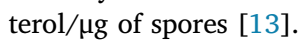

\subsubsection{Algae}

Three replicate aliquots of dried algae Scenedesmus obliquus and Chlorella vulgaris were processed according to the diagram of Fig. 1. The calculated $\mathrm{CV}$ values were $<10 \%$. Chlorophylls were found in the algae (about $10 \mathrm{ng} / \mathrm{mg}$ ), but the concentrations were lower than values found in other papers [29] probably due to a low recovery $(<10 \%)$. Alfatocoferol is present at around $30 \mathrm{ng} / \mathrm{mg}$ in both the algae according to other investigations [32].

Scenedesmus obliquus was richer of sterols than Chlorella and stigmasterol was the most abundant $(0.15-0.25 \mathrm{ng} / \mathrm{mg})$ followed by $\beta$-sitosterol $(0.02-0.1 \mathrm{ng} / \mathrm{mg})$ and minor amount of cholesterol.

\subsubsection{Environmental atmospheric sample}

The two sets of filters $\left(\mathrm{PM}_{<1}\right.$ an $\left.\mathrm{PM}_{>1}\right)$ were submitted to the whole procedure of Fig. 1 and Table 5 summarizes the concentrations of the biomarkers MUR, MDPA, DPA, ergosterol, and bacterial and fungal concentrations using the conversion factors of the Sections 3.3.1 and 3.3.2.

Bacterial concentrations obtained by MUR and MDPA are comparable in the two fractions, showing that both biomarkers are reliable, with a prevalence of bacteria in the finer fraction.

Bacterial spores are more abundant in the finer fraction and of the same order of bacterial cells in the same fraction. As expected, fungal spores are instead present only in the larger fraction and the concentration resulted several times (between 6 and 18) higher than those of bacteria in the same fraction.

Table 6 shows the results of the other investigated biomarkers
Table 5

Concentrations of the biomarkers MUR, MDPA, DPA, ergosterol, and relative bacterial and fungal concentrations.

\begin{tabular}{clccc}
\hline & & Size fraction & $\begin{array}{l}\text { Marker } \\
\text { concentration } \\
\mathrm{ng} \mathrm{m}^{-3}\end{array}$ & $\begin{array}{l}\text { Bioaerosolic } \\
\text { component } \\
\mathrm{ng} \mathrm{m}^{-3}\end{array}$ \\
\hline $\begin{array}{c}\text { Bacterial } \\
\text { cell }\end{array}$ & MUR & $\mathrm{PM}_{<1}$ & 0.10 & 17 \\
& MDPA & $\mathrm{PM}_{>1}$ & 0.060 & 9.0 \\
& \multirow{2}{*}{ AVERAGE } & $\mathrm{PM}_{<1}$ & 0.017 & 16 \\
Bacterial & DPA & $\mathrm{PM}_{<1}$ & 0.0090 & 8.2 \\
Fungal & ERGOSTEROL & $\mathrm{PM}_{>1}$ & & 16 \\
spore & & $\mathrm{PM}_{<1}$ & 2.2 & 8.6 \\
& & $\mathrm{PM}_{>1}$ & 0.33 & 3.4 \\
\hline
\end{tabular}

Table 6

Concentration ( $\mathrm{ng} \mathrm{m}^{-3}$ ) of the other investigated biomarkers in particulate matter samples.

\begin{tabular}{lcc}
\hline Compound & Size fraction & $\mathrm{ng} \mathrm{m}^{-3}$ \\
\hline \multirow{2}{*}{-sitosterol } & $\mathrm{PM}_{<1}$ & 0.14 \\
& $\mathrm{PM}_{>1}$ & 0.14 \\
Cholesterol & $\mathrm{PM}_{<1}$ & 0.24 \\
& $\mathrm{PM}_{>1}$ & 0.51 \\
Stigmasterol & $\mathrm{PM}_{<1}$ & n.d. \\
& $\mathrm{PM}_{>1}$ & n.d. \\
Chlorophylls a $+\mathrm{b}$ & $\mathrm{PM}_{<1}$ & n.d. \\
\multirow{3}{*}{$\alpha$-tocoferol } & $\mathrm{PM}_{>1}$ & 0.050 \\
& $\mathrm{PM}_{<1}$ & nd \\
& $\mathrm{PM}_{>1}$ & 0.050 \\
\hline
\end{tabular}

nd not detected.

namely other sterols, chlorophyll and $\alpha$-tocoferol in the two fractions of PM.

All the detected sterols are of the same order each other and in good compliance to other authors [33,34].

Among them, cholesterol is the most abundant sterol in both the fractions. It is lower in $\mathrm{PM}<1 \mu \mathrm{m}$, where it may be due to "meat cooking" [35], whereas in PM $>1 \mu \mathrm{m}$ it may come from animal cells and in minor part to vegetable and algae cells $[19,20]$. Among the phytosterols, only $\beta$-sitosterol was detected in both the fractions, whereas stigmasterol was not detected. In the investigated rural site, the absence of stigmasterol could suggest the absence of airborne algae, whereas the occurrence of $\beta$-sitosterol may be index of eukaryotic contribution of higher plants.

Alfa-tocoferol demonstrated to be unreliable marker, since during the analysis the concentration decreasing due to its oxidation.

In addition to the results about the fungal and bacterial contribution (summing cells and spore results), calculated by chemical markers, measurements were also carried out with the microbiological approach, measuring only the viable species (thanks to a PM parallel sampling). In order to make the results comparable (Table 7), we expressed the 
Table 7

Comparison between the proposed method (chemical) and the classical biological method for the determination of the fungal and bacterial components after two parallel samplings.

\begin{tabular}{|c|c|c|c|}
\hline & \multirow{2}{*}{$\begin{array}{l}\text { D. a. } \\
(\mu \mathrm{m})\end{array}$} & \multicolumn{2}{|l|}{ Montelibretti } \\
\hline & & $\begin{array}{l}\text { Chemical method ( } \mathrm{n}^{\circ} \text { cell- } \\
\text { spore } \mathrm{m}^{-3} \text { ) }\end{array}$ & $\begin{array}{l}\text { Biological method (CFU } \\
\mathrm{m}^{-3} \text { ) }\end{array}$ \\
\hline \multirow[t]{2}{*}{ Bacteria } & $<1$ & $5 \times 10^{4}$ & $2 \times 10^{1}$ \\
\hline & $>1$ & $1 \times 10^{4}$ & $2 \times 10^{2}$ \\
\hline \multirow[t]{2}{*}{ Fungi } & $<1$ & - & - \\
\hline & $>1$ & $9 \times 10^{2}$ & $9 \times 10^{1}$ \\
\hline
\end{tabular}

CFU = colony forming unit.

results as sum and approximated to the number of cells + spores, assuming the average weight of a bacterial cell $1 \mathrm{pg}$, of a bacterial spore $0.6 \mathrm{pg}$ and fungal spore $65 \mathrm{pg}$ [36]. As shown in Table 7, viable species are, as expected, lower than the total number $\mathrm{m}^{-3}$ of bacteria and fungi. In addition, for viable bacteria the ratio CFUPM ${ }_{>1} / \mathrm{CFUPM}_{<1}$ was 10, because of their arrangement in clusters or biofilms that allows their survival [37].

On the other hand, the bacteria obtained by chemical markers showed an opposite trend, since fraction $<1 \mu \mathrm{m}$ includes also noncultivable species (viable and non-viable) and bacterial fragments. We assumed that in the remote atmosphere under study, far from bacteria sources, the quantity of bacterial fragments and organic matter coming from deteriorate bacterial species was higher than viable vegetative cells and spores naturally found in the coarse fraction.

In $\mathrm{PM}_{>1}$ the total concentration of bacteria $\mathrm{m}^{-3}$ agreed with other authors (about $10^{4}$ bacteria $\mathrm{m}^{-3}$ in rural site) $[38,39]$. Concerning with fungi, the ratio between total fungal spore and viable fungi was 10 .

Overall, investigating only the viable contribution underestimates strongly the bacterial contribution in the atmosphere, because of noncultivability of many vital species or of the presence of dead microorganism in part due to the sampling, causing the mortality of viable species.

Also, the total biaerosol concentration was, in average, quite low, in accordance with the nature semi-rural of the investigated place, far from anthropic activities. However, the investigation of the bioaerosol components in this kind of site was useful for two main reasons:

1) it allowed to demonstrate the applicability of the method in places where bioaerosol is in traces.

2) the results may be considered as background contribution for other places, strongly polluted by bioaerosol.

To sum up it must be considered that, although the proposed method doesn't discriminate pathogenic species by contrast to other molecular biological techniques (such as qPCR, fluorescent UV-APS and WIBS), it provides a fast and useful tool for the evaluation of the total bioaerosol content.

A multidisciplinary approach should be considered to have a complete and in-depth view both of bioaerosol heterogeneity and of its concentration.

\section{Conclusion}

The aim of this paper was the study of a comprehensive method to determine the main components of bioaerosol, through the use of biomarkers. Different chemical markers were chosen to highlight, if present, peculiar or characteristic relationships between them, diagnostic and indicative of the presence of particular biological components. To sum up, the first part of this study, applied to fungi, bacteria and algae of known identity, allowed to verify the reliability, applicability and validity of the method. This was also important to provide basic information on some biomarkers related to a particular microorganism. Dipicolinic and muramic acids were reconfirmed and mesodiamminopimelic acid was proposed as new biomarker for bacterial cells, and the conversion factors were calculated and compared.

The ergosterol was re-confirmed and used as biomarker of fungal spores. As regard the other biomarkers some interesting results were obtained, but more data and evidences are necessary. For example, cholesterol is a qualitative marker of animal cells if present in fraction of $\mathrm{PM}>1 \mu \mathrm{m}$, but a small contribution is due to algae and vegetable cells. From our data the simultaneous presence of $\beta$-sitosterol together with stigmasterol may be a generic qualitative bio-indicator of algae, while the presence of only one of them could be a generic marker exclusively of plant cells.

In the second part of the study, the optimized method was applied to samples of PM, collected the research area of CNR of Montelibretti (near Rome) in the month of July. The bacterial and fungal components were determined, and the results were compared to those obtained by the classical microbiological methods. Due to the nature of the site, the total amount of bioaerosol components, obtained by chemical method, resulted quite low. On the other hand, the investigation of the only viable components underestimates strongly the total bioaerosol contribution in the atmosphere, because non-cultivable vital species and dead organisms are not included.

Other steps can be the investigation of archaea in bioaerosols, which are clinically significant components and the application of the method to PM sampled in workplaces where the concentration of bioaerosol is more severe. The results obtained in suburban rural site may be considered a starting point, underlining the worth of multidisciplinary approach, including chemical, microbiological and molecular biological methods for an accurate comparison between different types of data, which leads to a unilateral understanding of bioaerosol diversity and parallelly of the effects of bioaerosol on human health.

\section{Acknowledgment}

The authors wish to thank Prof. Francesca Pagnanelli for providing algae culture of Scenedesmus obliquus and Chlorella vulgaris.

\section{Funding}

The authors thank INAIL for the financial support by BRIC 2016 ID23.

\section{Appendix A. Supplementary data}

Supplementary data to this article can be found online at https:// doi.org/10.1016/j.microc.2019.103974.

\section{References}

[1] C. Humbal, S. Gautam, Ujwalkumar U. Trivedi, A review on recent progress in observations, and health effects of bioaerosols, Environ. Int. 118 (2018) 189-193.

[2] S. Sudharsanam, S. Swaminathan, A. Ramalingam, G. Thangavel, R. Annamalai, R. Steinberg, K. Balakrishnan, P., Srikanth, characterization of indoor bioaerosols from a hospital ward in a tropical setting, Afr. Health Sci. 12 (2012) 217-225.

[3] S. Makino, H.I. Cheun, Application of the real-time PCR for the detection of airborne microbial pathogens in reference to the anthrax spores, J. Microbiol. Methods 53 (2003) 141-147.

[4] A. Oppliger, F.G. Masclaux, H. Niculita-Hirzel, Assessment of airborne microorganisms by real-time PCR: optimistic findings and research challenges, Front. Biosci. (Schol. Ed.) 1 (2011) 445-453.

[5] A.J. Alvarez, M.P. Buttner, L.D. Stetzenbach, PCR for bioaerosol monitoring: sensitivity and environmental interference, Appl. Environ. Microbiol. 61 (1995) 3639-3644.

[6] J.D. Miller, J.C. Young, The use of ergosterol to measure exposure to fungal propagules in indoor air, Am. Ind. Hyg. Assoc. J. 58 (1997) 39-43.

[7] M.C. Pietrogrande, D. Bacco, M. Visentin, S. Ferrari, P. Casali, Polar organic marker compounds in atmospheric aerosol in the Po Valley during the Supersito campaigns-part 2: seasonal variations of sugars, Atm. Environ. 97 (2014) 215-225.

[8] A.K. Lee, C.K. Chan, M. Fang, A.P. Lau, The 3-hydroxy fatty acids as biomarkers for 
quantification and characterization of endotoxins and gram-negative bacteria in atmospheric aerosols in Hong Kong, Atmos. Environ. 38 (2004) 6307-6317.

[9] B. Ghosh, H. Lal, A. Srivastava, Review of bioaerosols in indoor environment with special reference to sampling, analysis and control mechanisms, Environ. Int. 85 (2015) 254-272.

[10] F. Buiarelli, V. Gallo, P. Di Filippo, D. Pomata, C. Riccardi, Development of a method for the analysis of underivatized amino acids by liquid chromatography/ tandem mass spectrometry: application on standard reference material 1649a (urban dust), Talanta 115 (2013) 966-972.

[11] P. Di Filippo, D. Pomata, C. Riccardi, F. Buiarelli, V. Gallo, A. Quaranta, Free and combined amino acids in size-segregated atmospheric aerosol samples, Atmos. Environ. 98 (2014) 179-189.

[12] F. Buiarelli, S. Canepari, P. Di Filippo, C. Perrino, D. Pomata, C. Riccardi, R. Speziale, Extraction and analysis of fungal spore biomarkers in atmospheric bioaerosol by HPLC-MS-MS and GC-MS, Talanta 105 (2013) 142-151.

[13] P. Di Filippo, D. Pomata, C. Riccardi, F. Buiarelli, C. Perrino, Fungal contribution to size-segregated aerosol measured through biomarkers, Atmos. Environ. 64 (2013) 132-140.

[14] P. Di Filippo, D. Pomata, C. Riccardi, F. Buiarelli, D. Uccelletti, E. Zanni, Muramic and dipicolinic acids in atmospheric particulate matter as biomarkers of bacteria and bacterial spores, Anal. Bioanal. Chem. 409 (2017) 1657-1666.

[15] N.K. Sharma, A.K. Rai, S. Singh, R.M. Brown Jr., Airborne algae: their present status and relevance, J. Phycol. 43 (2007) 615-627.

[16] N. Tlili, N. Nasri, E. Saadaoui, A. Khaldi, S. Triki, Sterol composition of caper (Capparis spinosa) seeds, Afr. J. Biotechnol. 9 (2010) 3328-3333.

[17] M. Aceves, J.O. Grimalt, J. Sunyer, J.M. Anto, C.E. Reed, Identification of soybean dust as an epidemic asthma agent in urban areas by molecular marker and RAST analysis of aerosols, J. Allergy Clin. Immunol. 88 (1991) 124-134.

[18] E.A. Stone, J.J. Schauer, B.B. Pradhan, P.M. Dangol, G. Habib, C. Venkataraman, V. Ramanathan, Characterization of emissions from South Asian biofuels and application to source apportionment of carbonaceous aerosol in the Himalayas, J. Geophys. Res. Atmos. 115 (2010).

[19] G. Lopes, C. Sousa, P. Valentao, P.B. Andrade, Sterols in algae and health, Bioactive Compounds from Marine Foods, 2013, pp. 173-191.

[20] E. Behrman, G. Venkat, Cholesterol and plants, J. Chem. Educ. 82 (2005) 1791-1793, https://doi.org/10.1021/ed082p1791.

[21] C. Pöhlker, J.A. Huffman, U. Pöschl, Autofluorescence of atmospheric bioaerosols-fluorescent biomolecules and potential interferences, Atmos. Meas. Tech. 5 (2012) 37-71.

[22] C.Y. Moreira dos Santos, D. de Almeida Azevedo, F.R. de Aquino Neto, Selected organic compounds from biomass burning found in the atmospheric particulate matter over sugarcane plantation areas, Atmos. Environ. 36 (2002) 3009-3019.

[23] P. Blais-Lecours, P. Perrott, C. Duchaine, Non-culturable bioaerosols in indoor settings: impact on health and molecular approaches for detection, Atmos. Environ. 110 (2015) 45-53.

[24] R. Rippka, J. Deruelles, J.B. Waterbury, M. Herdman, R.Y. Stanier, Generic assignments, strain histories and properties of pure cultures of cyanobacteria,
Microbiology 111 (1979) 1-61.

[25] P. Di Filippo, D. Pomata, C. Riccardi, F. Buiarelli, V. Gallo, Oxygenated polycyclic aromatic hydrocarbons in size-segregated urban aerosol, J. Aerosol Sci. 87 (2015) $126-134$

[26] F. Buiarelli, P. Di Filippo, D. Pomata, C. Riccardi, G. Simonetti, A rapid method for the determination of levoglucosan in NIST standard reference material 1649a by HPLC-MS/MS, Atmos. Environ. 195 (2018) 24-29.

[27] D. Pomata, P. Di Filippo, C. Riccardi, F. Buiarelli, V. Gallo, Determination of noncertified levoglucosan, sugar polyols and ergosterol in NIST standard reference material $1649^{\circ}$, Atmos. Environ. 84 (2014) 332-338.

[28] F. Buiarelli, F. Bernardini, G. Simonetti, P. Di Filippo, D. Pomata, C. Riccardi, R. Risoluti, A rapid and accurate method for the determination of methylxanthines in different nervous system stimulant beverages, J. AOAC Int. 102 (2019) 865-871.

[29] K.H. Wiltshire, M. Boersma, A. Möller, H. Buhtz, Extraction of pigments and fatty acids from the green alga Scenedesmus obliquus (Chlorophyceae), Aquat. Ecol. 34 (2000) 119-126.

[30] B.T. Shaffer, B. Lighthart, Survey of culturable airborne bacteria at four diverse locations in Oregon: urban, rural, forest, and coastal, Microb. Ecol. 34 (1997) 167-177.

[31] Z. Fang, Z. Ouyang, H. Zheng, X. Wang, L. Hu, Culturable airborne bacteria in outdoor environments in Beijing, China, Microb. Ecol. 54 (2007) 487-496.

[32] D.A. Esquivel-Hernández, J. Rodríguez-Rodríguez, M. Rostro-Alanis, S.P. CuéllarBermúdez, E.I. Mancera-Andrade, J.E. Núñez-Echevarría, J.S. García-Pérez, C. Rashmi, R. Parra-Saldívar, Advancement of green process through microwaveassisted extraction of bioactive metabolites from Arthrospira Platensis and bioac tivity evaluation, Bioresour. Technol. 224 (2017) 618-629.

[33] A.I. Rushdi, A.H. El-Mubarak, L. Lijotra, M.T. Al-Otaibi, M.A. Qurban, K.F. AlMutlaq, B.R.T. Simoneit, Characteristics of organic compounds in aerosol particulate matter from Dhahran city, Saudi Arabia, Arab. J. Chem. 10 (2017) S3532-S3547.

[34] T.S. Oliveira, C.A. Pio, C.A. Alves, A.J.D. Silvestre, M. Evtyugina, J.V. Afonso, P. Fialho, M. Legrand, H. Puxbaum, H. Gelencse'r, Seasonal variation of particulate lipophilic organic compounds at nonurban sites in Europe, J. Geophys. Res. 112 (2007) D23S09.

[35] M.J. Kleemana, M.A. Roberta, S.G. Riddleb, P.M. Finec, M.D. Haysd, J.J. Schauere, M.P. Hannigan, Size distribution of trace organic species emitted from biomass combustion and meat charbroiling, Atmos. Environ. 42 (2008) 3059-3075.

[36] B. Davis, R. Dulbecco, H. Eisen, H. Ginsberg, Bacterial Physiology: Microbiology, 2nd ed., Harper and Row, Maryland, 1973, pp. 96-97.

[37] J.M. Willey, L. Sherwood, C.J. Woolverton, Prescott's Principles of Microbiology, McGraw-Hill Higher Education, 2009 Chapter 5.

[38] R.M. Harrison, A.M. Jones, P.D.E. Biggins, N. Pomeroy, C.S. Cox, S.P. Kidd, J.L. Hobman, N.L. Brown, A. Beswick, Climate factors influencing bacterial count in background air samples, Int. J. Biometeorol. 49 (2005) 167-178.

[39] Y. Tong, Diurnal distribution of total and culturable atmospheric bacteria at a rural site, Aerosol Sci. Technol. 30 (1999) 246-254. 